\title{
Suppression of hepatocyte CYP1A2 expression by Kupffer cells via AhR pathway: The central role of proinflammatory cytokines
}

\author{
RONGQIAN WU ${ }^{1}$, XIAOXUAN CUI ${ }^{1}$, WEIFENG DONG ${ }^{1}$, MIAN ZHOU $^{1}$, H. HANK SIMMS $^{2}$ and PING WANG ${ }^{1}$ \\ ${ }^{1}$ Department of Surgery, North Shore University Hospital and Long Island \\ Jewish Medical Center, Manhasset, NY 11030, USA
}

Received February 6, 2006; Accepted March 23, 2006

\begin{abstract}
The hepatic cytochrome P-450 (CYP) enzyme system provides a major aspect of liver function, yet alterations of CYP in sepsis remain largely unknown. Although we have recently shown that CYP1A2, one of the major isoforms of CYP in rats, is downregulated in sepsis, the underlying mechanism and possible therapeutic approaches warrant further investigation. The aim of this study was to determine whether Kupffer cells (KCs) play any role in suppressing CYP1A2 in the hepatocytes (HCs) and if so, how to modulate CYP1A2 expression in sepsis. To study this, primary $\mathrm{KCs}$ and $\mathrm{HCs}$ were cultured separately or together with or without transwells. Cells and supernatant samples were collected after various stimulations. Additionally, polymicrobial sepsis was induced in rats by cecal ligation and puncture (CLP) with or without curcumin pre-treatment. Liver samples were harvested $20 \mathrm{~h}$ post-CLP. The results show that lipopolysaccharide (LPS) did not suppress CYP1A2 in $\mathrm{HC}$ or $\mathrm{HC} / \mathrm{KC}$ coculture with transwells. However, LPS downregulated CYP1A2, aryl hydrocarbon receptor (AhR, a nuclear receptor) and $\mathrm{AhR}$ nuclear translocator (Arnt) in coculture without transwells. Anti-TNF- $\alpha$ and anti-IL-1 $\beta$ antibodies attenuated this downregulation. Moreover, elevated hepatic levels of TNF- $\alpha$ and IL-1B post-CLP were decreased by curcumin pretreatment. This reduction was associated with increased expression of AhR and CYP1A2. These results indicate that KCs-derived proinflammatory cytokines may play an important role in downregulating CYP1A2 in sepsis. The reduction of $\mathrm{AhR} / \mathrm{Arnt}$ may be the underlying mechanism for
\end{abstract}

Correspondence to: Dr Ping Wang, Division of Surgical Research, The Feinstein Institute for Medical Research, 350 Community Drive, Manhasset, NY 11030, USA

E-mail: pwang@nshs.edu

Present address: ${ }^{2}$ Department of Surgery, Albert Einstein Medical Center, Philadelphia, PA 19141, USA

Key words: cytochrome P-450, sepsis, aryl hydrocarbon receptor, proinflammatory cytokines, curcumin such downregulation. Inhibition of proinflammatory cytokines by curcumin may provide a novel approach to modulate the hepatic CYP function in sepsis.

\section{Introduction}

Sepsis is the leading cause of death in non-cardiac intensive care units with $>210,000$ people succumbing to overwhelming infection (or the resultant multiple organ failure) in the US annually (1). Although experimental studies using cell and animal models have greatly improved our understanding of the pathophysiology of sepsis, there remains a remarkable paucity of information regarding the regulation of metabolism of pharmaceutical agents in this important public health problem. In particular, there is a need for better understanding the regulation of cytochrome P-450 (CYP) enzyme system under such conditions.

The hepatic CYP enzyme system constitutes one of the major aspects of hepatocyte function. Our recent studies have shown that one of the major hepatic P-450 isoforms in the rat, CYP1A2, is downregulated in sepsis (2). CYP1A2 is involved in the metabolism of various exogenous agents such as theophylline, imipramine, and naproxen and can be inhibited by chemicals such as cimetidine and fluoroquinolones (3). It is a major determinant of lidocaine metabolism, a commonly used hepatic CYP function measure (4). Inhibition of total CYPs produces exacerbated inflammatory responses and potentiated mortality in sepsis (2). The regulation of CYP by proinflammatory cytokines has been investigated $(5,6)$ However, the mechanism responsible for suppression of hepatic CYP1A2 in sepsis and possible therapeutic approaches to modulate CYP function under such conditions warrants further study.

Curcumin [1,7-bis(4-hydroxy-3-methoxyphenyl)-1,6heptadiene-3,5-dione], a polyphenol derived from the plant Curcuma longa and commonly called turmeric, has been used for hundreds of years as a safe anti-inflammatory agent in a variety of ailments as part of Indian traditional medicine. However, it is only within the past few years that the activity of curcumin against various diseases has been scientifically documented. Recent studies have shown that curcumin inhibits endotoxin-induced production of TNF- $\alpha$ and IL-1ß from macrophages (7-9). In a rat model of endotoxemia, curcumin has been shown to prevent the rapid transcription suppression 
of hepatic CYP isoforms (10). However, whether curcumin has a similar effect in a clinical relevant model of polymicrobial sepsis remained unknown.

Transcriptional activation of CYPs involves the aryl hydrocarbon receptor (AhR), a ligand-activated transcription factor as well as its nuclear translocator (Arnt) and a chaperone protein heat shock protein 90 (HSP90) (11-13). Using a Kupffer cell-hepatocyte coculture system and a rat model of polymicrobial sepsis, the present study was conducted to test the hypothesis that reduction in nuclear receptor $\mathrm{AhR}$, due to the increased production of $\mathrm{KC}$-derived cytokines plays an important role in suppressing hepatic CYP1A2 expression in sepsis; and that inhibition of proinflammatory cytokines by curcumin provides a novel therapeutic approach for the modulation of the hepatic CYP enzyme system under such conditions.

\section{Materials and methods}

Cell cultures. Rat KCs were isolated from 6- to 8-week-old normal male Sprague-Dawley rats by collagenase perfusion of the liver, isopycnic sedimentation in a Percoll gradient, and selective adherence (14). The viability of $\mathrm{KCs}$ was $>95 \%$ and the purity of KCs was $>85 \%$. Hepatocytes (HCs) were isolated from normal rats by collagenase perfusion and purified to $>95 \%$ purity by repeated centrifugation at $50 \mathrm{x}$ g followed by further purification over $50 \%$ Percoll (15). The viability of HCs was $>90 \%$. HCs were cultured at a density of $1 \times 10^{6}$ cells/ well in 24-well cell culture plates using Williams medium E containing $10 \%$ heat-inactivated bovine serum, supplemented with 15 mM HEPES (pH 7.4), 2 mM L-glutamine, 100 units/ $\mathrm{ml}$ penicillin, and $100 \mu \mathrm{g} / \mathrm{ml}$ streptomycin and placed in an incubator at $37^{\circ} \mathrm{C}$ in $5 \% \mathrm{CO}_{2} / 95 \%$ air. $\mathrm{KCs}$ were cultured in the same medium at a density of $1 \times 10^{6}$ cells/well in 24-well cell culture plates. The $\mathrm{HC}$ and $\mathrm{KC}$ coculture without transwells $(\mathrm{HC}+\mathrm{KC})$ consisted of $0.5 \times 10^{6}$, attached $\mathrm{KCs}$ in 24-well cell culture plates with the addition of $0.5 \times 10^{6} \mathrm{HCs}$ in direct contact. In order to eliminate the effect of direct cell to cell contact, a high pore density transwell membrane $(0.4 \mu \mathrm{m}$; Becton Dickinson Labware, Franklin Lakes, NJ) was used to separate HCs from KCs (allowing proteins to pass through). Briefly, the $\mathrm{HC}$ and $\mathrm{KC}$ cocultures with transwells $(\mathrm{HC}+\mathrm{KC} /$ Membrane) were prepared by culturing $0.5 \times 10^{6} \mathrm{KCs}$ at the bottom of 24-well cell culture plates and $0.5 \times 10^{6} \mathrm{HCs}$ plated on membrane inserts with a pore size of $0.4 \mu \mathrm{m}$. After a recovery period of $24 \mathrm{~h}$, medium was replaced by fresh medium with or without LPS $(100 \mathrm{ng} / \mathrm{ml})$ or TNF- $\alpha(0.02-2 \mathrm{ng} /$ $\mathrm{ml}), \mathrm{IL}-1 ß(0.02-2 \mathrm{ng} / \mathrm{ml})$ in all culture types.

Determination of CYP1A2, AhR, Arnt and HSP90 gene expression. The gene expression of CYP1A2, AhR, Arnt and HSP90 was measured by RT-PCR. The primers were as follows: 5' GAA TCG GTG GCT AAC GTC AT 3' (sense), 5' CCA GAA GAT GGC TGT TGT GA 3' (anti-sense) for CYP1A2 (NM-012541); 5' GGG ATC GAT TTC GAA GAC ATC AG 3' (sense), 5' AAC GCC TGG GAG CCT GGA ATC TC 3' (anti-sense) for AhR (NM-013149); 5' GCT ATA GTC ATT CCC AGG TTT CT 3' (sense), 5' CAT TGT TGT AGG TGT TGC TCT GG 3' (anti-sense) for Arnt (NM-012780), and 5'-ACA TCA TCC CCA ACC CTC-3' (sense), 5'-TCC
ACC AGC AGA AGA CTC C-3' (anti-sense) for HSP90 (S45392). Rat glyceraldehyde 3-phosphate dehydrogenase (G3PDH) served as a housekeeping gene (Clontech). PCR was carried out in a Bio-Rad thermal cycler. Optical densities of target and housekeeping gene bands were determined by the Bio-Rad image system (Hercules, CA). Target/housekeeping gene band density ratios were then calculated.

Determination of CYP1A2, AhR and Arnt proteins. The protein expression of CYP1A2, AhR and Arnt was measured by Western blotting. Briefly, $25 \mu \mathrm{g}$ proteins were fractionated on $4-12 \%$ Bis-Tris gel and transferred to $0.2 \mu$ m-nitrocellulose membrane. Nitrocellulose blots were blocked by incubation in TBST (10 mM Tris-HCl, pH 7.5, $150 \mathrm{mM} \mathrm{NaCl}, 0.1 \%$ Tween-20) containing 5\% milk for $1 \mathrm{~h}$. Blots were incubated with goat anti-rat CYP1A2 serum (1:600; Daiichi Pure Chemicals, Tokyo, Japan), rabbit anti-rat AhR polyclonal antibody (1:600; BioMol Research Laboratories Inc., Plymouth Meeting, PA) and goat anti-rat Arnt polyclonal antibody (1:150; Santa Cruz Biotechnology, Inc., Santa Cruz, CA) overnight at $4^{\circ} \mathrm{C}$, respectively. The blots were then washed in TBST for $5 \times 10$ min. Blots were incubated with HRP labeled anti-goat $(1: 4000)$ or anti-rabbit $(1: 10000)$ IgG for $1 \mathrm{~h}$ at room temperature. The blots were then washed in TBST for $5 \times 10$ min. A chemiluminescent peroxidase substrate (ECL, Amersham Biosciences, Inc.) was applied according to the manufacturer's instructions, and the membranes were exposed briefly to X-ray film. The band densities were normalized by actin using the Bio-Rad image system.

Determination of TNF- $\alpha$ and IL-1 $\beta$. TNF- $\alpha$ and IL- $1 \beta$ levels in the supernatant were quantified using enzyme-linked immunosorbent assay (ELISA) kits, specifically for rat TNF- $\alpha$ and IL-1ß (BioSource International, Camarillo, CA). The assay was carried out according to the instructions provided by the manufacturer.

Neutralization of TNF- $\alpha$ and IL-1 $\beta$ bioactivity. In order to determine the effect of TNF- $\alpha$ and IL-1 $1 \beta$ in the expression of CYP1A2, both anti-TNF- $\alpha$ and anti-IL-1ß antibodies $(10 \mu \mathrm{g} /$ $\mathrm{ml}$ and $1 \mu \mathrm{g} / \mathrm{ml}$, respectively; R\&D Systems Inc., Minneapolis, $\mathrm{MN}$ ) were used in the coculture system ( $\mathrm{KC}+\mathrm{HC}$ group only).

Animal model of sepsis. Male Sprague-Dawley rats (275-325 g) were housed in a temperature-controlled room on a 12-h light/ dark cycle and fed a standard Purina rat chow diet. Prior to the induction of sepsis, rats were fasted overnight but allowed water ad libitum. Rats were anesthetized with isoflurane inhalation, and the ventral neck, abdomen and groin were shaved and washed with $10 \%$ povidone iodine. Cecal ligation and puncture (CLP) was performed as we previously described (16) and the animals were randomly assigned to various groups. All experiments were performed in accordance with the NIH guidelines for the use of experimental animals. This project was approved by the Institutional Animal Care and Use Committee of the Feinstein Institute for Medical Research, North Shore-Long Island Jewish Health System.

Administration of curcumin. Curcumin (Sigma Chemical, St. Louis, MO) was dissolved in 50\% DMSO:50\% DMEM 


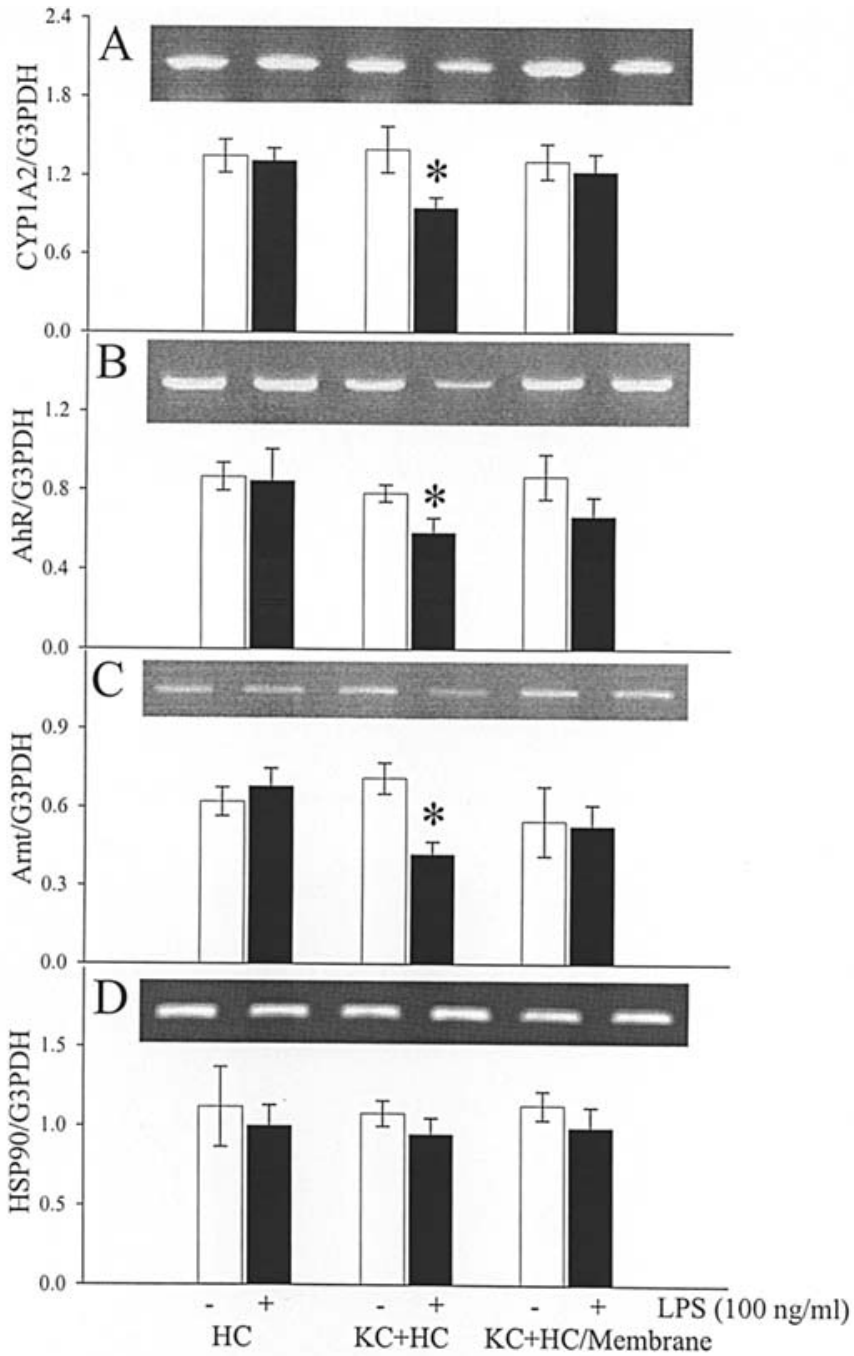

Figure 1. Alterations in mRNA expressions of CYP1A2 (A), AhR (B), Arnt (C) and HSP90 (D) in hepatocyte (HC), hepatocyte and Kupffer cell cocultures $(\mathrm{HC}+\mathrm{KC})$, and hepatocyte and Kupffer cell cocultures with transwell membrane insert (HC+KC/Membrane) with or without $100 \mathrm{ng} / \mathrm{ml}$ LPS stimulation for $24 \mathrm{~h}$. Representative blots are also presented. Data are expressed as means \pm SE ( $n=6 /$ group) and compared by Student's t-test: ${ }^{*} \mathrm{P}<0.05$ versus Medium-LPS group.

to a final concentration of $1 \mathrm{mM}$. Mini-pumps $(2 \mathrm{ml})$ (Alzet, $10 \mu \mathrm{l} / \mathrm{h}$ for 7 days) were primed with curcumin solution or vehicle (50\% DMSO:50\% DMEM) overnight prior to implantation. After a bolus intravenous injection of $0.2-\mu \mathrm{mol}$ curcumin or 200- $\mu 1$ vehicle, the mini-pumps were connected to a jugular vein catheter and then implanted subcutaneously. Three days after the implantation, rats were subjected to sepsis by CLP. Twenty hours after CLP (i.e., the late, hypodynamic phase of sepsis), the animals were sacrificed and liver samples were collected. The total dosage of curcumin given to each animal in this experiment was $4 \mu \mathrm{mol} / \mathrm{kg} \mathrm{BW}$. The gene expression and protein levels of CYP1A2 and AhR in the liver were determined by RT-PCR and Western blots, respectively. Hepatic levels of TNF- $\alpha$ and IL-1ß were measured by ELISA.

Statistical analysis. All data are expressed as means \pm SE and compared by Student's t-test or one-way analysis of variance (ANOVA) and Tukey's test. Differences in values were considered significant at $\mathrm{P}<0.05$.

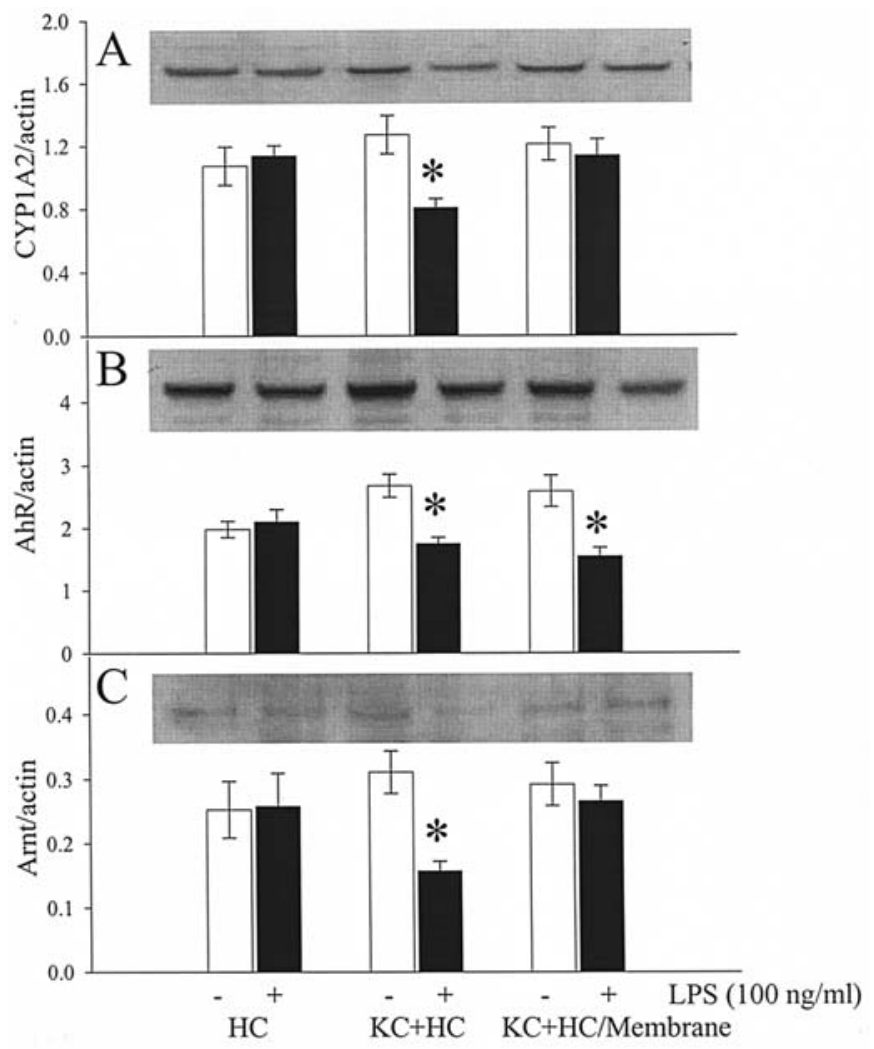

Figure 2. Alterations in protein levels of CYP1A2 (A), AhR (B), Arnt (C) in hepatocytes $(\mathrm{HC})$, hepatocyte and Kupffer cell cocultures $(\mathrm{HC}+\mathrm{KC})$, and hepatocyte and Kupffer cell cocultures with transwell membrane insert (HC+KC/Membrane) with or without $100 \mathrm{ng} / \mathrm{ml}$ LPS stimulation for $24 \mathrm{~h}$. Representative blots are also presented. Data are expressed as means $\pm \mathrm{SE}$ ( $\mathrm{n}=5-6 /$ group) and compared by Student's t-test: ${ }^{*} \mathrm{P}<0.05$ versus MediumLPS group.

\section{Results}

Alterations in the expression of CYP1A2, AhR, Arnt, and $H S P 90$ and the release of $T N F-\alpha$ and $I L-1 \beta$ in a Kupfer cell $(\mathrm{KC})$-hepatocyte $(\mathrm{HC})$ coculture system. As shown in Fig. 1A, LPS did not affect CYP1A2 mRNA expression in HCs. When $\mathrm{HCs}$ and $\mathrm{KCs}$ were cocultured with direct contact (i.e., $\mathrm{KC}+\mathrm{HC}$ group), however, CYP1A2 mRNA expression decreased by $32 \%(\mathrm{P}<0.05$, Fig. $1 \mathrm{~A})$. Since CYP1A2 expression is significantly higher in $\mathrm{HCs}$ than in KCs (data not shown), the decreased CYP1A2 detected in the coculture system was primarily due to the decreased expression of CYP1A2 in HCs. When a high pore density transwell membrane $(0.4-\mu \mathrm{m})$ was used to separate HCs from KCs (allowing proteins to pass through), the decreased CYP1A2 mRNA expression was prevented (Fig. 1 A; KC+HC/Membrane group). Similar results were also observed in AhR and Arnt mRNA expression (Fig. 1B-C), but HSP90 gene expression was not significantly altered under such in vitro conditions (Fig. 1D). The protein expression of CYP1A2 (58 kDa), AhR $(95 \mathrm{kDa})$ and Arnt $(90 \mathrm{kDa})$ was also significantly reduced in $\mathrm{KC}+\mathrm{HC}$ group (AhR was also reduced in $\mathrm{KC}+\mathrm{HC} / \mathrm{Membrane}$ group; Fig. 2A-C). Since the gene expression of HSP90 was not altered in all groups, its protein expression was not measured. To determine whether the downregulated CYP1A2, 


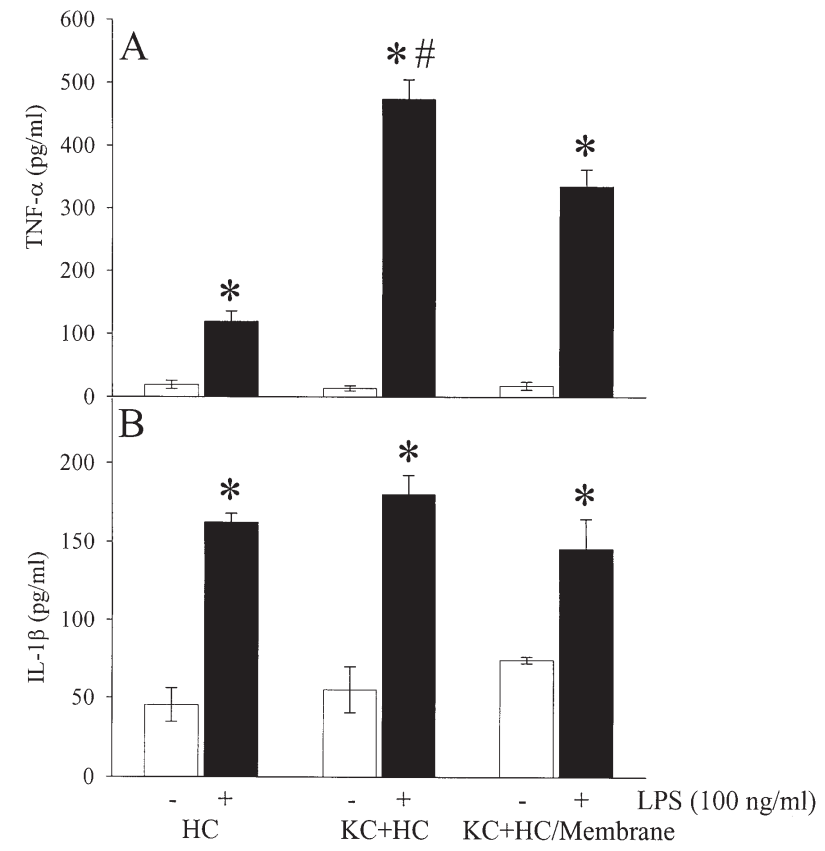

Figure 3. Alterations in TNF- $\alpha$ (A) and IL-1ß (B) levels in tissue culture supernatants of hepatocytes $(\mathrm{HC})$, hepatocyte and Kupffer cell cocultures $(\mathrm{HC}+\mathrm{KC})$, and hepatocyte and Kupffer cell cocultures with transwell membrane insert $(\mathrm{HC}+\mathrm{KC} / \mathrm{Membrane})$ with or without $100 \mathrm{ng} / \mathrm{ml}$ LPS stimulation for $24 \mathrm{~h}$. Data are expressed as means $\pm \mathrm{SE}$ ( $\mathrm{n}=6 /$ group) and compared by ANOVA and Tukey's test: " $\mathrm{P}<0.05$ versus Medium-LPS; ${ }^{\text {" }} \mathrm{P}<0.05$ versus $\mathrm{HC}$ group or $\mathrm{HC}+\mathrm{KC} / \mathrm{Membrane}$ group with LPS stimulation.

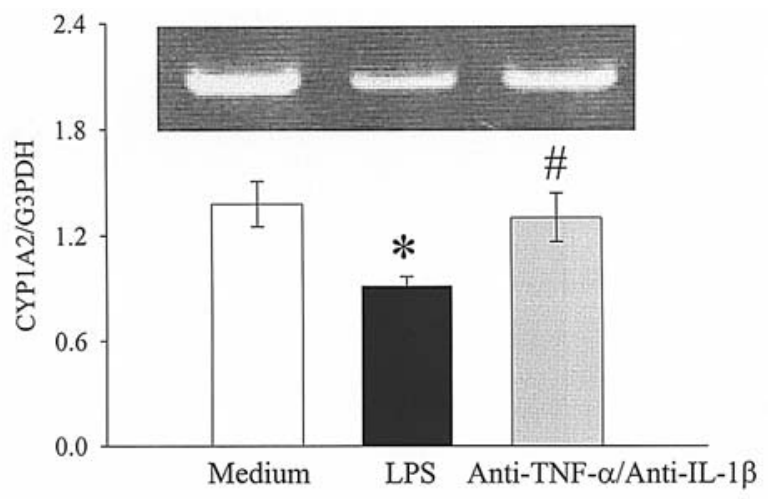

Figure 4. Effects of anti-TNF- $\alpha(10 \mu \mathrm{g} / \mathrm{ml})$ and anti-IL-1ß $(1 \mu \mathrm{g} / \mathrm{ml})$ antibodies on CYP1A2 mRNA expressions in hepatocyte and Kupffer cell cocultures with $100 \mathrm{ng} / \mathrm{ml}$ LPS stimulation for $24 \mathrm{~h}$. A representative blot is also presented. Data are expressed as means $\pm \mathrm{SE}$ ( $\mathrm{n}=6$ /group) and compared by ANOVA and Tukey's test: ${ }^{*} \mathrm{P}<0.05$ versus Medium group; ${ }^{~} \mathrm{P}<0.05$ versus LPS group.

AhR and Arnt are related with greater cytokine release, TNF- $\alpha$ and IL-1ß levels in the supernatant were measured. As indicated in Fig. 3A and B, coculture with the direct cell contact ( $\mathrm{KC}+\mathrm{HC}$ group) produced the highest TNF- $\alpha$ and IL$1 \beta$ levels (IL-1ß was less impressive compared to TNF- $\alpha$ ), suggesting that $\mathrm{TNF}-\alpha$ in association with IL-1ß may play a role in downregulating CYP1A2 expression after LPS stimulation. To confirm this, both anti-TNF- $\alpha$ and anti-IL-1ß antibodies were used in the coculture system $(\mathrm{KC}+\mathrm{HC}$ group only). The results indicate that LPS-induced downregulation

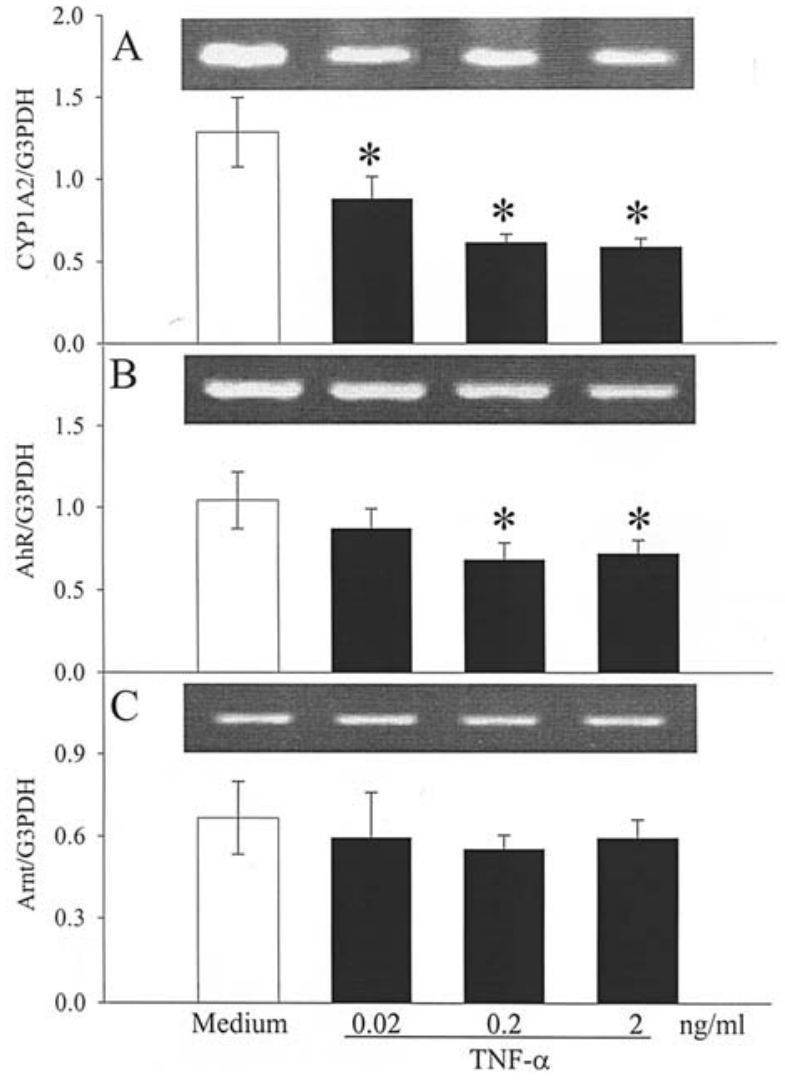

Figure 5. Alterations in CYP1A2 (A), AhR (B), and Arnt (C) mRNA expressions in hepatocytes stimulated with various concentrations of TNF- $\alpha$ for $48 \mathrm{~h}$. Representative blots are also presented. Data are expressed as means \pm SE ( $n=6 /$ group) and compared by ANOVA and Tukey's test: ${ }^{*} \mathrm{P}<0.05$ versus Medium group.

of CYP1A2 gene expression was prevented by inhibition of TNF- $\alpha$ and IL-1ß (Fig. 4).

Effects of TNF- $\alpha$ and IL-1 $\beta$ on CYPIA2, AhR, and Arnt in primary hepatocyte culture. Hepatocytes were isolated from normal rats and cultured with or without TNF- $\alpha(0.02-2 \mathrm{ng} / \mathrm{ml})$ or IL-1ß $(0.02-2 \mathrm{ng} / \mathrm{ml})$ for $48 \mathrm{~h}$. CYP1A2, AhR and Arnt gene expression was determined using RT-PCR technique. The results indicate that incubation of hepatocytes with physiologically relevant amounts of TNF- $\alpha$ concentrationdependently decreased the gene expression of CYP1A2 and AhR (Fig. 5A and B) without an affect of Arnt expression (Fig. 5C). Similarly, incubation of hepatocytes with IL-1ß for $48 \mathrm{~h}$ reduced CYP1A2 and AhR expression (Fig. 6A and B), but not Arnt expression (Fig. 6C).

Effects of curcumin administration on hepatic TNF- $\alpha$ and IL-1 $\beta$ expression in sepsis. As shown in Fig. 7A and B, hepatic levels of TNF- $\alpha$ and IL- $1 \beta$ increased significantly at $20 \mathrm{~h}$ after CLP. Curcumin treatment markedly attenuated TNF- $\alpha$ and IL-1ß levels in the liver.

Effects of curcumin administration on hepatic CYP1A2, AhR expression in sepsis. The gene and protein expression of CYP1A2 was decreased significantly $20 \mathrm{~h}$ after CLP, and curcumin treatment significantly improved their expression (Fig. 8A and B). Likewise, reduced AhR gene and protein 


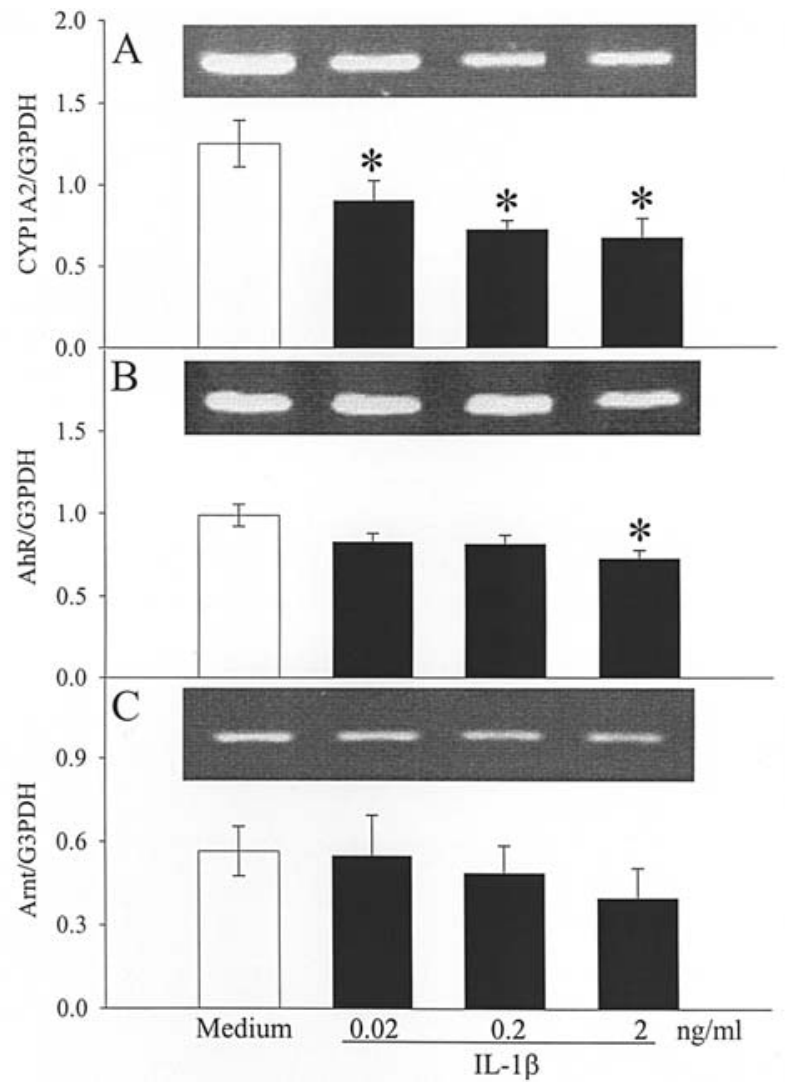

Figure 6. Alterations in CYP1A2 (A), AhR (B), and Arnt (C) mRNA expressions in hepatocytes stimulated with various concentrations of IL-1B for $48 \mathrm{~h}$. Representative blots are also presented. Data are expressed as means \pm SE ( $n=6 /$ group) and compared by ANOVA and Tukey's test: ${ }^{*} \mathrm{P}<0.05$ versus Medium group.

expression was also prevented after curcumin treatment (Fig. 9A and B).

\section{Discussion}

Expression of hepatic CYP can be affected genetically or environmentally. Environmental factors known to alter CYP isoforms include medications (e.g. barbiturates, anticonvulsants, rifampin), food (cruciferous vegetables), social habits (alcohol consumption, cigarette smoking), development, and disease conditions (diabetes, inflammation, and infection) (17). Mediators involved in inflammation and sepsis can alter the drug metabolizing capabilities of hepatic CYPs (18-21) Proinflammatory cytokines play an important role in the regulation of CYP expression $(5,6)$. When stimulated with TNF- $\alpha$, IL- $1 \beta$, IFN- $\gamma$ or IL- 6 , the expression of various CYP isoforms in cultured cells is downregulated (22-26). There is a decrease in CYP isoforms in animal models of endotoxemia and in cultured hepatocytes stimulated by endotoxin (18,27-32). However, very little work has been performed with hepatic CYP in animal models of sepsis aside from measuring mixed function oxidase (33) and comparing CYP3A expression in sepsis with endotoxic shock (34). In this regard, our recent studies have shown that rat hepatic CYP1A2 mRNA was significantly downregulated at 10-20 h and its protein expression decreased at $20 \mathrm{~h}$ after CLP (2). The observation that hepatic CYP1A2 gene expression

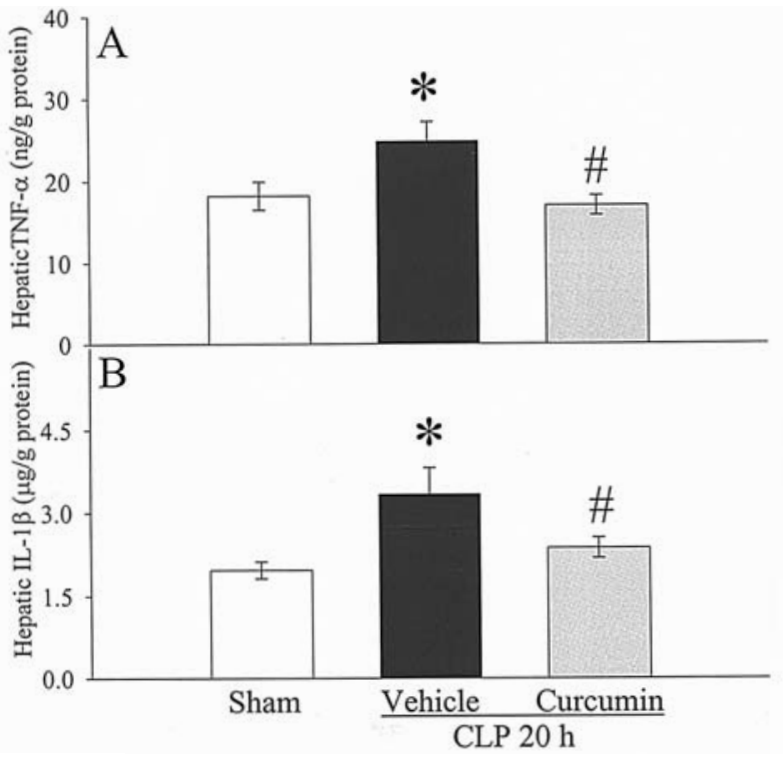

Figure 7. Effects of curcumin treatment on hepatic levels of TNF- $\alpha$ (A) and IL-1ß (B) in rats subjected to sepsis by cecal ligation and puncture (CLP). Data are expressed as mean $\pm \mathrm{SE}$ ( $\mathrm{n}=6$ /group) and compared by ANOVA and Tukey's test: ${ }^{*} \mathrm{P}<0.05$ versus Sham; ${ }^{\text {}} \mathrm{P}<0.05$ versus $\mathrm{CLP}+$ Vehicle.

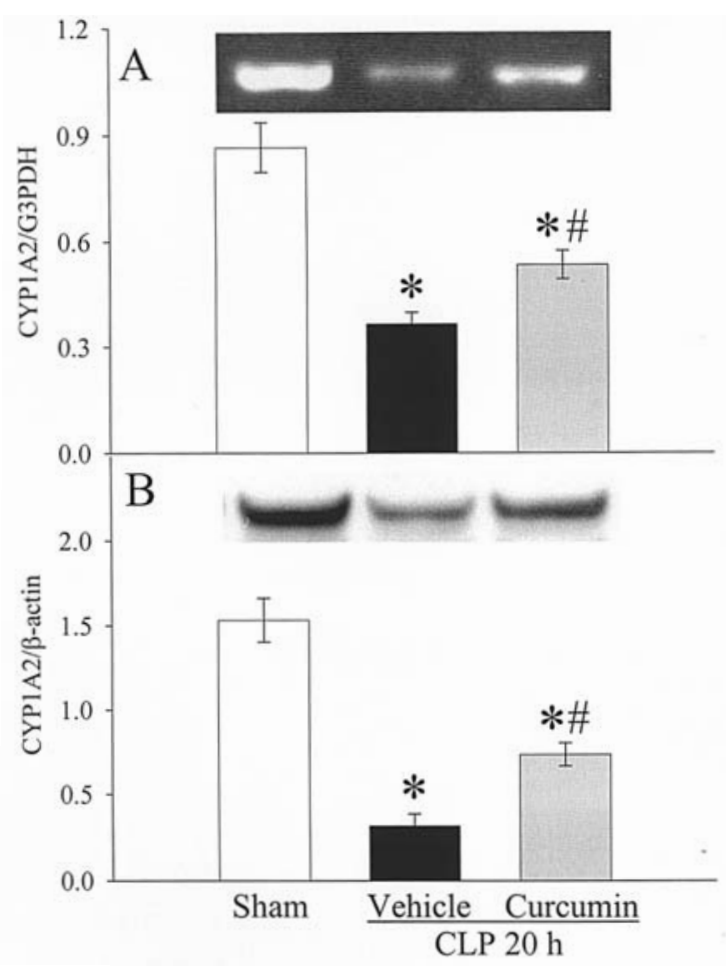

Figure 8. Effects of curcumin treatment on CYP1A2 gene expression (A) and protein levels (B) in liver homogenates in rats subjected to sepsis by cecal ligation and puncture (CLP). Representative blots for CYP1A2 mRNA and proteins are also presented. Data are expressed as mean $\pm \mathrm{SE}$ ( $\mathrm{n}=6 /$ group) and compared by ANOVA and Tukey's test: ${ }^{*} \mathrm{P}<0.05$ versus Sham; ${ }^{*} \mathrm{P}<0.05$ versus CLP+Vehicle.

decreased when hepatic perfusion increased at the early stage of sepsis (i.e. $10 \mathrm{~h}$ after CLP) (35) which indicates that other factors may participate in the suppression of hepatic CYP function in sepsis. The fact that plasma levels of endotoxin 


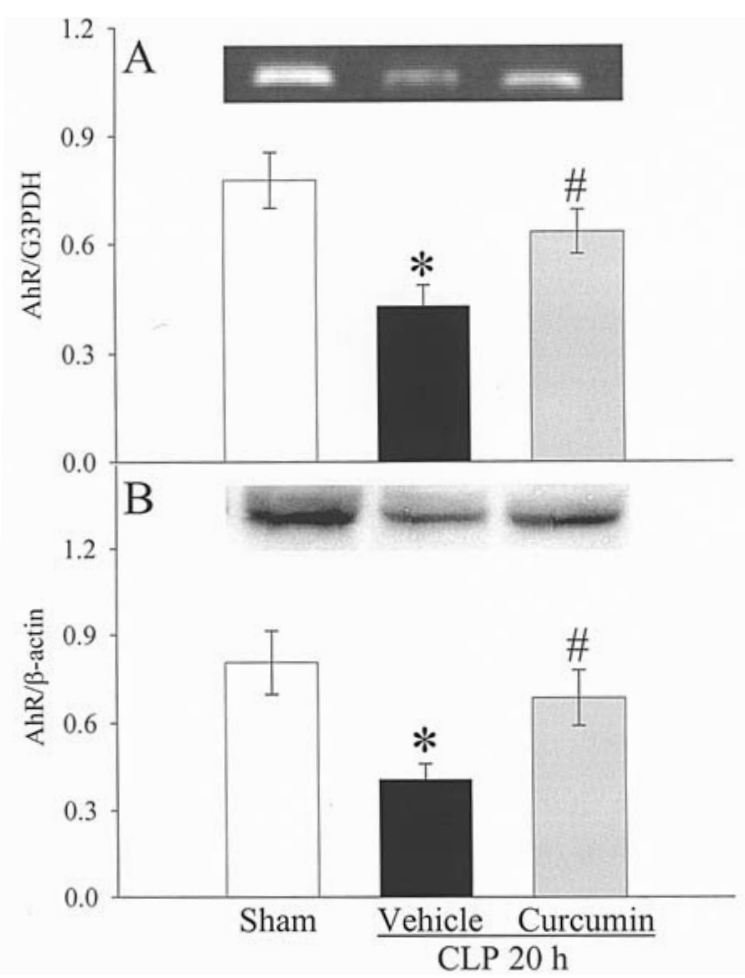

Figure 9. Effects of curcumin treatment on AhR gene expression (A) and protein levels (B) in liver homogenates in rats subjected to sepsis by cecal ligation and puncture (CLP). Representative blots for AhR mRNA and proteins are also presented. Data are expressed as mean $\pm \mathrm{SE}$ ( $n=6 /$ group) and compared by ANOVA and and Tukey's test: ${ }^{*} \mathrm{P}<0.05$ versus Sham; ${ }^{\#} \mathrm{P}<0.05$ versus $\mathrm{CLP}+\mathrm{V}$ ehicle.

and proinflammatory cytokines such as TNF- $\alpha$ and IL-1ß increase very early after the onset of sepsis implies the possible role of LPS, TNF- $\alpha$ and IL- $1 \beta$ on the suppression of CYP1A2 expression under such conditions. Using a $\mathrm{KC}$ and HC coculture system, our present study indicates that LPS did not suppress CYP1A2 expression in $\mathrm{HC}$ alone or $\mathrm{HC} / \mathrm{KC}$ coculture with transwells. In the presence of direct cell-to-cell contact between HC and KC, however, LPS significantly downregulated CYP1A2 expression. Moreover, proinflammatory cytokine levels especially $\mathrm{TNF}-\alpha$ in the supernatants of coculture without transwells were much higher than any other groups. TNF- $\alpha$ and IL- $1 \beta$ alone also inhibited CYP1A2 gene expression, but additional time of stimulation was needed ( $24 \mathrm{~h}$ vs. $48 \mathrm{~h}$ ). Anti-TNF- $\alpha$ and antiIL-1ß antibodies attenuated the down-regulatory effect of LPS on CYP1A2 gene expression in $\mathrm{HC}$ and $\mathrm{KC}$ coculture with direct cell-to-cell contact. These results, taken together, indicate that proinflammatory cytokines released from $\mathrm{KC}$, but not direct effects of LPS, play an important role in downregulating hepatic CYP1A2 expression in sepsis.

Nuclear receptors represent a superfamily of ligandmodulated transcription factors that mediate responses to steroids, retinoids, thyroid hormones, and various xenobiotics (36). These receptors play a key role in development, cell differentiation, and organ physiology (37). Unlike watersoluble hormones, steroid hormones can enter the cell by simple or facilitated diffusion and transduce their signals to the genome via intracellular receptors (38). After binding to its receptor, the hormone-receptor complex moves from the cytoplasm to the nucleus, undergoing allosteric changes that enable the complex to bind to high affinity sites in the chromatin and modulate gene transcription (39). More than 70 distinct members of the nuclear receptor superfamily have been identified (40). Studies have shown that the transcription of CYP1A2 gene is mediated through the aryl hydrocarbon receptor (AhR) signaling pathway (11-13). This is further supported by the finding that the human hepatoma cell line SK-Hep-1, which expresses defective AhR, is associated with the lack of CYP1A2 expression (41). In the absence of stimulation, AhR exists as a non-DNA-binding, $\sim 300 \mathrm{kDa}$ heteromeric complex, associated with the molecular chaperone heat shock protein 90 (HSP90) in a 1:2 ratio in the cytosol (42). Upon stimulation, AhR-HSP90 complex enters the nucleus and subsequently dissociates, enabling AhR to be phosphorylated by tyrosine kinase. Activated AhR then forms a heterodimer complex with its nuclear translocator (AhR nuclear translocator, Arnt) (43). Within the nucleus, the AhR-Arnt complex recognizes and binds to the specific regulatory sequences known as the dioxin responsive element (DRE) at the promoter region, and initiates the transcription of the CYP1A2 gene $(44,45)$. HSP90 appears to be critical for folding of a ligandbinding conformation in $\mathrm{AhR}$ and for the ligand's inducibility $(46,47)$. In this study, we found that the inhibition of CYP1A2 expression is associated with reduced levels of AhR/Arnt under both in vitro and in vivo conditions. Therefore, the inhibition of AhR/Arnt expression may be the underlying mechanism for downregulation of CYP1A2.

Curcumin is the major yellow pigment extracted from turmeric, a commonly used spice derived from the rhizome of the herb Curcuma longa. In the Indian subcontinent and Southeast Asia, turmeric has traditionally been used as a treatment for inflammation and skin wounds. Clinical activity of curcumin has yet to be confirmed; however, curcumin has known anti-inflammatory properties in preclinical animal models (48). Curcumin is cytoprotective, and suppresses the hepatic microvascular inflammatory response to endotoxin as demonstrated by its inhibitory effects on $\mathrm{KC}$ activation, neutrophil adhesion, and endothelial cell swelling (49,50). In animal models, curcumin prevents ethanol-induced liver injury as well as ethanol and nonethanol experimental pancreatitis $(51,52)$. Pre-treatment with curcumin attenuates hemorrhageinduced increases in proinflammatory cytokines and improves organ function under such conditions (53). Our recent study also demonstrates that curcumin inhibits endotoxin-induced production of TNF- $\alpha$ from macrophages, as well as reduces circulating levels of TNF- $\alpha$ and attenuates organ injury in a CLP model of sepsis (54). In this study, we found that significantly elevated hepatic levels of TNF- $\alpha$ and IL-1ß after CLP were reduced by curcumin treatment. This reduction in TNF- $\alpha$ and IL- $1 \beta$ is associated with increased expression of AhR and CYP1A2 in the liver. Therefore, the restoration of hepatic CYP1A2 expression by curcumin treatment in septic animals is mediated through downregulation of proinflammatory cytokines involving an AhR/Arnt dependent pathway. Since the CYP enzyme system is essential in inflammation, and its inhibition leads to exacerbated proinflammatory responses and tissue injury, the beneficial effect of curcumin in sepsis is at least partially mediated by the restoration of hepatic CYP function. 
In summary, proinflammatory cytokines released from $\mathrm{KC}$, but not direct effects of LPS, play an important role in downregulating hepatic CYP1A2 expression in sepsis. The reduction of AhR/Arnt expression may be the underlying mechanism for such downregulation. Inhibition of proinflammatory cytokines by curcumin may provide a novel therapeutic approach for the modulation of the hepatic CYP enzyme system under such conditions.

\section{Acknowledgements}

This study was supported by NIH grant R01 GM053008 (P.W.); Dr Rongqian Wu is supported by a Postdoctoral Fellowship from the American Heart Association (the Heritage Affiliate) No. 0325802T.

\section{References}

1. Angus DC, Linde-Zwirble WT, Lidicker J, Clermont G, Carcillo J and Pinsky MR: Epidemiology of severe sepsis in the United States: analysis of incidence, outcome, and associated costs of care. Crit Care Med 29: 1303-1310, 2001.

2. Crawford JH, Yang S, Zhou M, Simms HH and Wang P: Downregulation of hepatic CYP1A2 plays an important role in inflammatory responses in sepsis. Crit Care Med 32: 502-508, 2004.

3. Spatzenegger M, Horsmans Y and Verbeeck RK: Differential activities of CYP1A isozymes in hepatic and intestinal microsomes of control and 3-methylcholanthrene-induced rats. Pharmacol Toxicol 86: 71-77, 2000.

4. Orlando R, Piccoli P, De Martin S, Padrini R, Floreani M and Palatini P: Cytochrome P450 1A2 is a major determinant of lidocaine metabolism in vivo: effects of liver function. Clin Pharmacol Ther 75: 80-88, 2004.

5. Abdel-Razzak Z, Loyer P, Fautrel A, Gautier JC, Corcos L, Turlin B, Beaune P and Guillouzo A: Cytokines down-regulate expression of major cytochrome P-450 enzymes in adult human hepatocytes in primary culture. Mol Pharmacol 44: 707-715, 1993.

6. Muntane-Relat J, Ourlin JC, Domergue J and Maurel P: Differential effects of cytokines on the inducible expression of CYP1A1, CYP1A2, and CYP3A4 in human hepatocytes in primary culture. Hepatology 22: 1143-1153, 1995.

7. Chan MM: Inhibition of tumor necrosis factor by curcumin, a phytochemical. Biochem Pharmacol 49: 1551-1556, 1995.

8. Jang MK, Sohn DH and Ryu JH: A curcuminoid and sesquiterpenes as inhibitors of macrophage TNF-alpha release from Curcuma zedoaria. Planta Med 67: 550-552, 2001.

9. Abe Y, Hashimoto S and Horie T: Curcumin inhibition of inflammatory cytokine production by human peripheral blood monocytes and alveolar macrophages. Pharmacol Res 39: 41-47, 1999.

10. Cheng PY, Wang M and Morgan ET: Rapid transcriptional suppression of rat cytochrome $\mathrm{P} 450$ genes by endotoxin treatment and its inhibition by curcumin. J Pharmacol Exp Ther 307: 1205-1212, 2003

11. Honkakoski P and Negishi M: Regulation of cytochrome P450 (CYP) genes by nuclear receptors. Biochem J 347: 321-337, 2000.

12. Waxman DJ: P450 gene induction by structurally diverse xenochemicals: central role of nuclear receptors CAR, PXR, and PPAR. Arch Biochem Biophys 369: 11-23, 1999.

13. Hankinson O: The aryl hydrocarbon receptor complex. Annu Rev Pharmacol Toxicol 35: 307-340, 1995.

14. Wu R, Zhou M and Wang P: Adrenomedullin and adrenomedullin binding protein-1 downregulate TNF-alpha in macrophage cell line and rat Kupffer cells. Regul Pept 112: 19-26, 2003.

15. Mahmoud MSW, Wang P and Chaudry IH: Salutary effects of ATP- $\mathrm{MgCl}_{2}$ on the altered hepatocyte signal transduction after hemorrhagic shock. Am J Physiol 272: G1347-G1354, 1997.

16. Wu R, Cui X, Lim YP, Bendelja K, Zhou M, Simms HH and Wang P: Delayed administration of human inter-alpha inhibitor proteins reduces mortality in sepsis. Crit Care Med 32: 1747-1752, 2004.

17. De Paepe P, Belpaire FM and Buylaert WA: Pharmacokinetic and pharmacodynamic considerations when treating patients with sepsis and septic shock. Clin Pharmacokinet 41: 1135-1151, 2002 .
18. Morgan ET: Regulation of cytochromes P450 during inflammation and infection. Drug Metab Rev 29: 1129-1188, 1997.

19. Piscitelli SC, Reiss WG, Figg WD and Petros WP: Pharmacokinetic studies with recombinant cytokines. Scientific issues and practical considerations. Clin Pharmacokinet 32: 368-381, 1997.

20. Haas CE, Kaufman DC, Jones CE, Burstein AH and Reiss W: Cytochrome P450 3A4 activity after surgical stress. Crit Care Med 31: 1338-1346, 2003.

21. Carcillo JA, Doughty L, Kofos D, Frye RF, Kaplan SS, Sasser H and Burckart GJ: Cytochrome P450 mediated-drug metabolism is reduced in children with sepsis-induced multiple organ failure. Intensive Care Med 29: 980-984, 2003.

22. Morgan ET: Suppression of constitutive cytochrome P-450 gene expression in livers of rats undergoing an acute phase response to endotoxin. Mol Pharmacol 36: 699-707, 1989.

23. Bertini R, Bianchi M, Erroi A, Villa P and Ghezzi P: Dexamethasone modulation of in vivo effects of endotoxin, tumor necrosis factor, and interleukin-1 on liver cytochrome P-450, plasma fibrinogen, and serum iron. J Leukoc Biol 46: 254-262, 1989.

24. Barker CW, Fagan JB and Pasco DS: Interleukin-1 beta suppresses the induction of P4501A1 and P4501A2 mRNAs in isolated hepatocytes. J Biol Chem 267: 8050-8055, 1992.

25. Sujita K, Okuno F, Tanaka Y, Hirano Y, Inamoto Y, Eto S and Arai M: Effect of interleukin 1 (IL-1) on the levels of cytochrome P-450 involving IL-1 receptor on the isolated hepatocytes of rat. Biochem Biophys Res Commun 168: 1217-1222, 1990.

26. Fukuda Y, Ishida N, Noguchi T, Kappas A and Sassa S: Interleukin-6 down regulates the expression of transcripts encoding cytochrome P450 IA1, IA2 and IIIA3 in human hepatoma cells. Biochem Biophys Res Commun 184: 960-965, 1992.

27. McKindley DS, Boulet J, Sachdeva K, Wang P and Chichester C: Endotoxic shock alters the pharmacokinetics of lidocaine and monoethylglycinexylidide. Shock 17: 199-204, 2002.

28. Shedlofsky SI, Israel BC, McClain CJ, Hill DB and Blouin RA: Endotoxin administration to humans inhibits hepatic cytochrome P450-mediated drug metabolism. J Clin Invest 94: 2209-2214, 1994.

29. Monshouwer M, McLellan RA, Delaporte E, van Miert AS, Witkamp RF and Renton KW: Differential effect of pentoxifylline on lipopolysaccharide-induced downregulation of cytochrome P450. Biochem Pharmacol 52: 1195-1200, 1996.

30. Iber H, Sewer MB, Barclay TB, Mitchell SR, Li T and Morgan ET: Modulation of drug metabolism in infectious and inflammatory diseases. Drug Metab Rev 31: 29-41, 1999.

31. Morgan ET: Regulation of cytochrome p450 by inflammatory mediators: why and how? Drug Metab Dispos 29: 207-212, 2001.

32. Oyekan AO: The suppression by lipopolysaccharide of cytochrome P450-dependent renal vasodilation in the rat is mediated by nitric oxide. Eur J Pharmacol 277: 123-132, 1995.

33. Godellas CV, Williams JF and Fabri PJ: Mixed-function oxidase activity in sepsis. J Surg Res 59: 783-786, 1995.

34. Sachdeva K, Yan B and Chichester CO: Lipopolysaccharide and cecal ligation/puncture differentially affect the subcellular distribution of the pregnane $\mathrm{X}$ receptor but consistently cause suppression of its target genes CYP3A. Shock 19: 469-474, 2003.

35. Wang P and Chaudry IH: Mechanism of hepatocellular dysfunction during hyperdynamic sepsis. Am J Physiol 270: R927-R938, 1996

36. Greschik H and Moras D: Structure-activity relationship of nuclear receptor-ligand interactions. Curr Top Med Chem 3: 1573-1599, 2003.

37. Beato M, Herrlich P and Schutz G: Steroid hormone receptors: many actors in search of a plot. Cell 83: 851-857, 1995.

38. Mangelsdorf DJ, Thummel C, Beato M, Herrlich P, Schutz G, Umesono K, Blumberg B, Kastner P, Mark M and Chambon P: The nuclear receptor superfamily: the second decade. Cell 83: 835-839, 1995.

39. Forman BM, Chen J and Evans RM: The peroxisome proliferatoractivated receptors: ligands and activators. Ann NY Acad Sci 804: 266-275, 1996

40. Handschin $\mathrm{C}$ and Meyer UA: Induction of drug metabolism: the role of nuclear receptors. Pharmacol Rev 55: 649-673, 2003.

41. Roberts EA, Harper PA, Wong JM, Wang Y and Yang S: Failure of Ah receptor to mediate induction of cytochromes P450 in the CYP1 family in the human hepatoma line SK-Hep-1. Arch Biochem Biophys 384: 190-198, 2000. 
42. Gradin K, McGuire J, Wenger RH, Kvietikova I, Fhitelaw ML, Toftgard R, Tora L, Gassmann M and Poellinger L: Functional interference between hypoxia and dioxin signal transduction pathways: competition for recruitment of the Arnt transcription factor. Mol Cell Biol 16: 5221-5231, 1996.

43. Tomita S, Sinal CJ, Yim SH and Gonzalez FJ: Conditional disruption of the aryl hydrocarbon receptor nuclear translocator (Arnt) gene leads to loss of target gene induction by the aryl hydrocarbon receptor and hypoxia-inducible factor 1alpha. Mol Endocrinol 14: 1674-1681, 2000.

44. Reyes H, Reisz-Porszasz S and Hankinson O: Identification of the Ah receptor nuclear translocator protein (Arnt) as a component of the DNA binding form of the Ah receptor. Science 256: 1193-1195, 1992.

45. Whitelaw M, Pongratz I, Wilhelmsson A, Gustafsson JA and Poellinger L: Ligand-dependent recruitment of the Arnt coregulator determines DNA recognition by the dioxin receptor. Mol Cell Biol 13: 2504-2514, 1993.

46. Coumailleau P, Poellinger L, Gustafsson JA and Whitelaw ML: Definition of a minimal domain of the dioxin receptor that is associated with Hsp90 and maintains wild type ligand binding affinity and specificity. J Biol Chem 270: 25291-25300, 1995.

47. Whitelaw ML, McGuire J, Picard D, Gustafsson JA and Poellinger L: Heat shock protein hsp90 regulates dioxin receptor function in vivo. Proc Natl Acad Sci USA 92: 44374441,1995

48. Chainani-Wu N: Safety and anti-inflammatory activity of curcumin: a component of tumeric (Curcuma longa). J Altern Complement Med 9: 161-168, 2003.
49. Dunsmore KE, Chen PG and Wong HR: Curcumin, a medicinal herbal compound capable of inducing the heat shock response. Crit Care Med 29: 2199-2204, 2001.

50. Lukita-Atmadja W, Ito Y, Baker GL and McCuskey RS: Effect of curcuminoids as anti-inflammatory agents on the hepatic microvascular response to endotoxin. Shock 17: 399-403, 2002.

51. Nanji AA, Jokelainen K, Tipoe GL, Rahemtulla A, Thomas P and Dannenberg AJ: Curcumin prevents alcohol-induced liver disease in rats by inhibiting the expression of NF-kappa Bdependent genes. Am J Physiol Gastrointest Liver Physiol 284: G321-G327, 2003.

52. Gukovsky I, Reyes CN, Vaquero EC, Gukovskaya AS and Pandol SJ: Curcumin ameliorates ethanol and nonethanol experimental pancreatitis. Am J Physiol Gastrointest Liver Physiol 284: G85-G95, 2003.

53. Gaddipati JP, Sundar SV, Calemine J, Seth P, Sidhu GS and Maheshwari RK: Differential regulation of cytokines and transcription factors in liver by curcumin following hemorrhage/ resuscitation. Shock 19: 150-156, 2003.

54. Siddiqui A, Cui X, Wu R, Dong W, Zhou M, Hu M, Simms HH and Wang P: Mechanism responsible for the anti-inflammatory effects of curcumin in sepsis: upregulation of peroxisome proliferator-activated receptor- $\gamma$ (PPAR- $\gamma$ ). Shock 21 (Suppl 2): $22-23,2004$ 